\title{
INEQUALITIES VIA HARMONIC CONVEX FUNCTIONS: CONFORMABLE FRACTIONAL CALCULUS APPROACH
}

\author{
Muhammad Uzair Awan, Muhammad Aslam Noor, \\ MARCELA V. MiHAi AND KHALIDA INAYAT NOOR
}

Abstract. The main objective of this paper is to establish some conformable fractional estimates of Hermite-Hadamard type integral inequalities via harmonic convex functions. Mathematics subject classification (2010): 26D15, 26A51, 26A33.

Keywords and phrases: Convex, harmonic, fractional, conformable, Hermite-Hadamard.

\section{REFERENCES}

[1] T. Abdeljawad, On conformable fractional calculus, J. Comput. Appl. Math., 279 (2015), 57-66.

[2] G. CRistescu, L. Lups A, Non-connected Convexities and Applications, Kluwer Academic Publishers, Dordrecht, Holland, 2002.

[3] S. S. Dragomir, R. P. Agarwal, Two inequalities for differentiable mappings and applications to special means of real numbers and to trapezoidal formula, Appl. Math. Lett. 11 (1998), 91-95.

[4] S. S. Dragomir, C. E. M. PeArCe, Selected topics on Hermite-Hadamard inequalities and applications, Victoria University, Australia, 2000.

[5] I. IsCAN, Hermite-Hadamard type inequalities for harmonically convex functions, Hacettepe J. Math. Stat. 43 (6), 935-942, (2014).

[6] I. IsCAN, S. WU, Hermite-Hadamard type inequalities for harmonically convex functions via fractional integrals, Appl. Math. Comput., 238, 237-244, (2014).

[7] A. Kilbas, H. M. SRivastaVa, J. J. Trujillo, Theory and applications of fractional differential equations, Elsevier B. V., Amsterdam, Netherlands, (2006).

[8] R. Khalil, M. Al Horani, A. Yousef, M. Sababheh, A new definition of fractional derivative, J. Computat. Appl. Math., 264 (2014), 65-70.

[9] M. V. Mihai, M. A. Noor, K. I. Noor, M. U. Awan, Some integral inequalities for harmonic h-convex functions involving hypergeometric functions, Appl. Math. Comput. 252, 257-262, (2015).

[10] K. S. MiLler, B. Ross, An introduction to the fractional calculus and fractional differential equations, New York: Wiley, 1993.

[11] M. A. Noor, K. I. Noor, M. U. Awan, Integral inequalities for coordinated harmonically convex functions, Complex Var. Elliptic Equat. 60 (6), 776-786, (2015).

[12] M. A. Noor, K. I. Noor, M. U. Awan, S. Costache, Some integral inequalities for harmonically h-convex functions, U. P. B. Sci. Bull., Series A. 77 (1), 5-16, (2015).

[13] M. Z. SARIKAYA, E. SET, H. YAldiz, N. BASAK, Hermite-Hadamard's inequalities for fractional integrals and related fractional inequalities, Math. Comput. Model., 57 (2013), 2403-2407.

[14] E. SET, New inequalities of Ostrowski type for mappings whose derivatives are $s$-convex in the second sense via fractional integrals, Comput. Math. Appl., 63 (7), (2012), 1147-1154.

[15] E. Set, A. O. Akdemir, I. Mumcu, The Hermite-Hadamard's inequality and its extentions for conformable fractioanal integrals of any order $\alpha>0$, preprint, (2016).

[16] E. Set, M. Z. Sarikaya, A. GozPInar, Some Hermite-Hadamard type inequalities for convex functions via conformable fractional integrals and related inequalities, preprint, (2016).

[17] H.-N. SHI AND J. ZHAng, Some new judgement theorems of Schur geometric and Schur harmonic convexities for a class of symmetric functions, J. Inequal. Appl. 2013 (2013), 527. 